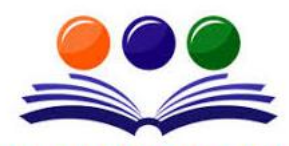

GRAND ACADEMIC PORTAL RESEARCH JOURNALS

\title{
FORENSIC ACCOUNTING: AN OVERVIEW IN INDIAN CONTEXT
}

\author{
Dr. Nirali Ketan Shah \\ Department of Accountancy \\ Assistant Professor, Gujarat Arts \& Commerce College (Eve), Ahmedabad
}

\begin{abstract}
The rudiments objective of GAAP states that the financial statements must depict 'true and fair' view of the financial state of affairs. The ambivalence of 'true and fair' view created a dodge towards the rise of financial frauds, thereby wearying the trust of the users of financial information on the reported statements. Forensic accounting as new area of accounting in India has come to limelight recently due to quick increase in white collar crimes, financial crimes, cyber-crimes and growing complexities of the corporate environment. Forensic accounting is the triple practice that integrates accounting, auditing and investigative skills to conduct an examination into a company's financial statements. The object of this study is to know the detailed conceptual clarity regarding the term Forensic Accounting. The study covered the necessary information regarding knowing the term Forensic Accounting, its definition, characteristics, objectives scope, role of a forensic accounting investigator and modus operandi (Techniques). It also covered differentiating points among the accounting, audit \& forensic accounting. More over the well-known case of fraud has also been taken in the study. The data was collected to understand the objectives of forensic accounting and challenges faced by forensic investigators while examining various cases. The research largely makes use of secondary sources of data and the previous literature on forensic accounting, along with the experts' views on the same. There is an urgent need to regularize the forensic accounting movement by the government and recognized accounting bodies in India.
\end{abstract}

\section{INTRODUCTION OF FORENSIC ACCOUNTING}

Cracking down on fraud is critical for a country that needs investment. Forensic accounting is the area which is called upon to address the issues of prevention and investigation of white collar crimes. In the emerging economic scenario, forensic accounting also known as forensic auditing is a vital tool for finding of financial crime and the direction of justice, providing decisive information about the facts found related to financial crime. Forensic accounting is hardly a new field, but in recent years, banks, insurance companies and even police agencies have increased the use of these experts. The increase in white collar crime and the hitches faced by law enforcement agencies in finding fraud have also contributed to the growth of the profession. A key piece of proof is the report of the forensic accountant. India is hitherto to meet the growing demand for fraud examiners because of a shortage of training institutions; Demand for fraud examiners is growing fast because of the use of information technology to commit crimes, growing business competition. Opportunities for forensic accountants are increasing rapidly in recent years due to a rise in white collar crime.

\section{HISTORY OF FORENSIC ACCOUNTING}

In India the first recorded history of Forensic Accounting is a specialized field within credited to the Mauryans. Reference to the discipline is accounting that conducts investigation about frauds, found in Arthashastra (Science of Material Wealth) of including analysis of various financial records and Kautilya. Forensic accounting known as triangle of the integration of accounting, auditing and investigative skills creates the specialty. In Mauryan Times, Kautilya was the first person to indication the well-known 40 ways of fraudulent in his famous Kautilyaarthashastra during the ancient In India. The research is initiated in India with a great rapidity and Pradeep Akkunoor pioneers the topic and has done a good research about the contribution of Kautilya in Forensic accounting. Kautilya back in to the 21st Century called by Pradeep who heads Journal of Forensic accounting in India and have started the series of schmooze between the computer and Kautilya. Birbal was used various tricks to investigate various crimes in the time of King Akbar. Some of his stories give the fraud examiner aephemeral idea about the Litmus test of investigation. Chetan Dalal who is the Gem of Indian Fraud Examiners, can be credited with actually applying the stories of the Birbal to the Investigation of the frauds. In various articles published in BCAS Journal he has explained how Birbal"s trap and Birbal"s Litmus test approaches are significantly used while investigating the accounting frauds.Though Forensic Accounting in amount of water that is drunk by a swimming fish'. The present form is of recent origin, the discipline has a long Kautilya can also be credited of being the first ever author history that dates back to centuries. An examination of this to articulate the views about Forensic Accounting as well as long history of this discipline, and its vast potential in the need for forensic accountants. Current world would definitively be informative and 


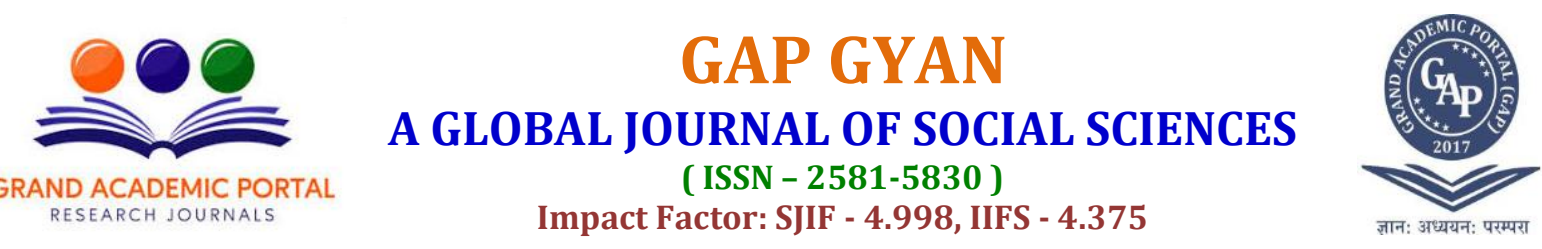

another classical example of Forensic Accounting was that timely of Archimedes. Without damaging the imperial crown, Archimedes was proficient of determining that it is not completely made of gold. This was done through the recent version of Forensic Accounting determining the density of the crown by measuring the Meaning of Forensic Accounting.displacement of water. In the court of Mogul emperor According to him the most important component of the Akbar, Birbal his courtier used certain tricks to investigate auditor's job is fraud detection, and a good auditor is one various crimes of officials. India is the most corrupt of the BRICs. China is modestly less corrupt than Russia, while Brazil is basically at lowest. India has another problem of frauds -- as high as 40 percent -- committed by vendors and suppliers in India, and significantly higher than the BRIC countries and the global average of 32 percent.

\section{RECENT HISTORY}

In current present scenario, forensic accounting has recognized itself as dynamic and strategic tool in combating corruption, crime and frauds through investigations and resolving allegations of frauds and embezzlements in India. These instances cannot who is invariably capable of detecting frauds. However be considered as a 'formal' form of Forensic the terminology 'Forensic Accounting' was coined by Accounting. Maurice E. Peloubet in 1946. The term was introduced in recent history his essay entitled 'Forensic Accounting: It's Place in the recent history of Forensic Accounting is credited to Today's Economy'. This discipline was used extensively Lawrence Dicksee (1892). He wrote a near to during the World War II by various governments across the comprehensive book (Published in America in 1905), globe. However, the formalized procedures with respect to entitled 'Auditing: A Practical Manual for Auditors'. In this Forensic Accounting came into being only in the 1980s. It book he listed three audit objectives: was during this time that a number of academic studies were published in the field (Rasey, 2009). Now Forensic means,

1. Detection of fraud, Accounting has become a specialty area of the accountancy

2. Detection of technical errors, and profession dealing with engagements that could lead to actual or anticipated disputes or litigation. A number of

3. Detection of errors in principle.

Experts attempted to define what Forensic Accounting is. A few such definitions are provided in Table 1.

Table-1

\begin{tabular}{|c|c|c|}
\hline $\begin{array}{l}\text { Sr. } \\
\text { No. }\end{array}$ & Institution/Authors & Definitions \\
\hline 1 & AICPA (1993) & $\begin{array}{l}\text { "Forensic accounting is the application of accounting principles, theories, and } \\
\text { discipline to facts or hypotheses at issues in a legal dispute and encompasses } \\
\text { every branch of accounting knowledge." }\end{array}$ \\
\hline 2 & KPMG (1999) & $\begin{array}{l}\text { Forensic Accounting as assistance in disputes which are likely to involve } \\
\text { litigation, arbitration, expert determination, mediation or an enquiry by an } \\
\text { appropriate regulatory authority, and investigation of suspected frauds, } \\
\text { irregularity or impropriety which could potentially lead to civil, criminal or } \\
\text { disciplinary proceedings; while focusing primarily on accounting issues. }\end{array}$ \\
\hline 3 & $\begin{array}{l}\text { American Institute of } \\
\text { Certified Public } \\
\text { Accountants (AICPA) } \\
\text { (2004) }\end{array}$ & $\begin{array}{l}\text { "the use of professional accounting skills in matters involving potential or } \\
\text { actual civil or criminal litigation, including, but not limited to, Generally } \\
\text { Acceptable Accounting Principle; the determination of lost profit, income, } \\
\text { assets, or damages; evaluation of internal controls; fraud; and any other matter } \\
\text { involving accounting expertise in the legal system" }\end{array}$ \\
\hline 4 & $\begin{array}{l}\text { Arokiasamy and } \\
\text { Cristal-Lee (2009) }\end{array}$ & $\begin{array}{l}\text { "the application of auditing methods, techniques or procedures to resolve legal } \\
\text { issues that require the integration of investigative, accounting, and auditing } \\
\text { skills". }\end{array}$ \\
\hline 5 & (Kasum, 2009). & $\begin{array}{l}\text { Forensic accounting also called investigative accounting or fraud audit is a } \\
\text { merger of forensic science and accounting }\end{array}$ \\
\hline 6 & $\begin{array}{l}\text { Stanbury and Paley - } \\
\text { Menzies, (2010). }\end{array}$ & $\begin{array}{l}\text { "the gathering, interpreting, summarizing and presentingcomplex financial } \\
\text { issues in a clear, succinct and factualmanner often in a court of law as an } \\
\text { expert" }\end{array}$ \\
\hline 7 & Zia (2010) & $\begin{array}{l}\text { "The science that deals with the relation and application of finance, accounting, } \\
\text { tax and auditing knowledge to analyse, investigate, inquire, test and examine } \\
\text { matters in civil law, criminal law and jurisprudence in an attempt to obtain the } \\
\text { truth from which to render an expert opinion" }\end{array}$ \\
\hline 8 & $\begin{array}{l}\text { Ozkul and Pamukc } \\
(2012)\end{array}$ & $\begin{array}{l}\text { "the application of accounting and auditing, financialand investigative skills, to } \\
\text { unsettled issues, conductedwithin the context of the rules of evidence" }\end{array}$ \\
\hline 9 & $\begin{array}{l}\text { Association of } \\
\text { Certified Fraud }\end{array}$ & $\begin{array}{l}\text { "Application of accounting principles, theories, anddiscipline to facts or } \\
\text { hypotheses at issues in a legaldispute and encompasses every branch of }\end{array}$ \\
\hline
\end{tabular}




\begin{tabular}{|l|l|} 
A GLOBAL JOURNAL OF SOCIAL SCIENCES \\
( ISSN - 2581-5830 ) \\
ImpanD ACADEMIC PORTAL \\
RESEARC JOURNALS
\end{tabular}

\section{LITERATURE REVIEW}

Prof. Megha Naik (2019), studied that the scope and role of a forensic accounting investigator in fraud detection. In India, forensic accounting has come into limelight due to increase in scams or white collar crimes. The data was collected to understand the objectives of forensic accounting and challenges faced by forensic investigators while examining various cases.

Parul Shair (2017), examined that the scope and modus operandi of forensic accounting in the backdrop of rising corporate frauds in India. The research largely makes use of secondary sources of data and the previous it enrapture on forensic accounting, along with the experts' views on the same. In a nutshell, the research suggested that immense possibilities for forensic accounting to assume a separate 'niche' and provides opportunities for forensic experts to offer litigation support, investigative accounting, and consulting services. There was an urgent need to regularize the forensic accounting movement by the government and recognized accounting bodies in India. There was much scope for advancements in the forensic accounting techniques and legislation in the wake of unrelenting number and complexity of corporate frauds and economic crimes.

Joshi (2003) renowned the commencing of forensic accounting to Kautilya, the first economist to openly recognize the need for the forensic accountant whom he said, mentioned 40 ways of fraud centuries ago. He, however, stated that the term "forensic accounting was coined by Peloubet in 1946.

Dr. Manas Chakrabarti (2014), examined that the discusses on the problems and prospects of forensic accounting, as profession in India on the basis secondary data collected from various sources.

Mr. Pema Lama , Mr. Brahma Chaudhuri (2018) evaluated the focuses on the conceptual framework, various provisions and applicability of forensic accounting in investigating corporate frauds and scams in IndiaWith the growing complexities of business and commercial operations, the financial irregularities alsoincreases because of the mindless obsession with profit maximization at any cost when carried to any extremecan lead to failures like Enron, Worldcom, Satyam has extreme negative impact on the survival andgrowth of any economic entity. But there are no appropriate conventional accountings and auditing proceduresthat can provide absolute assurance in preventing and detecting all fraudulent financial reporting. As amechanism to detect and prevent corporate frauds and scams, forensic accounting has emerged as a relativelynew and effective tool in the hands of accountants to find out mistakes and malpractices in accounting world.

Dr. Mahua Biswas, Kiran G Hiremath, Shalini R, (2013) studied to understand the significance of forensic accounting in the wake of recent financial scams in India and to highlight the problems of forensic accounting in India. The information is collected from the secondary sources. In India due to the complex and traditional judicial system, political compulsion etc., forensic accountants are facing the challenge of gathering information against „big shots" that is admissible in the court of law. It has been suggested that appointment of forensic accountants should be made mandatory in public sector and large scalecompanies.Forensic accounting is used for fraud examination and fraud examination covers fraud allegations from inception to disposition, including obtaining evidence, interviewing, writing reports, and testifying.

Ifath Shaheen, Pranathi, Asra Sultana and AmathunNoor(2014) studied to the role of forensic accounting in fraud examination in India and to understand the various applications of forensic accounting in Indian firms. In India unfortunately it is being used as an investigative tool, rather than a preventive tool. If forensic auditing is made mandatory in various sectors, many of the scams can be restricted. It has been suggested that appointment of forensic accountants should be made mandatory in public sectors and large scale companies for the sustainable development of the economy.

Bhavish Jugurnath, Roucheet Bissessur, Youvish Ramjattan, Hema Soondrum, Akshay Seedoyal (2017) Evaluated The Awareness Of Forensic Accounting in Mauritius and the behaviour of three different types of companies, accounting and auditing firms, multinational companies and local companies with respect to forensic accounting. A survey was carried out and distributed among these stated types of companies. Out of the 100 questionnaires distributed, 54 responses were collected, amounting to a response rate of 54\%. The responses were collected and processed using SPSS and the results show that 5 out of 8 questions relative to awareness of forensic accounting are significant with gender and 3 out of 8 questions related to awareness of forensic accounting is significant with the variable type of company. 


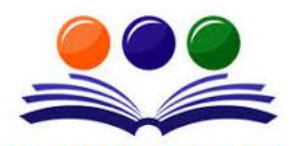

GRAND ACADEMIC PORTAL RESEARCH JOURNALS

\section{A GLOBAL JOURNAL OF SOCIAL SCIENCES}

( ISSN - 2581-5830 )

Impact Factor: SJIF - 4.998, IIFS - 4.375

$>$ To refurbish the demoted public confidence.

$>$ To formulate and establish a wide-ranging corporate governance policy and the statutory audit function.

$>$ To create a optimistic work milieu and help reinforce auditors' impartiality.

\section{SCOPE OF FORENSIC ACCOUNTING IN INDIA}

Due to An increase in white collar crimes and frauds, scandals in public as well as private sectors, there is a wide scope for forensic accounting in India. Forensic accounting covers two far-reaching areas of practice. These are litigation support and investigative accounting. Thus, forensic accounting rendezvous and investigation is typically substantially longer than any other investigation. The scope of Forensic Accounting is much more broadened, specific and elaborated as equate to Financial Accounting \& Auditing.

$>$ Forensic accountant detects fraud by analyzing the financial matters, financial statements, financial reporting systems, management information systems, company's method of operations, business structure, accounting principles and by following internal and external auditing procedures.

$>$ Forensic accounting helps to gathers proofs and investigates the tactics, litigation procedures to construe the results

$>$ Forensic accounting designs and performs statutory audit procedures for risk reduction of the business

$>$ Design accounting processes for verifying important premises and data. A forensic accounting orientation also calls for skills in identifying possible fraud.

$>$ Forensic accountant or auditor acts as an advisor to the audit committee

$>$ Forensic accountant helps in the research activities of the investment analyst, economic Offences Wings also required during the Due Diligence in case of Mergers and Acquisition.

Cover a wide assortment of businesses and locations that require uninterrupted surveillance of all transaction processing systems.

\section{MERITS OF FORENSIC ACCOUNTING}

1. Fraud Identification and Preclusion: - fraud is quite common in large organizations where the number of daily financial transactions is gigantic. In such anmilieu, an employee can easily undertake fraudulent activities without being caught. Forensic accounting helps in analysing whether the company's accounting policies are followed or not, any deviation observed in the books of accounts can help in identifying fraud, and necessary measures can be taken to thwart it in the future.

2. Structure of Economic Policies - various cases of fraud that becomes manifest after forensic analysis act as a mention for the government to formulate improved economic policies that would be able to curtail such fraudulent activities in the future. By doing so, the government can reinforce the economy and thwart such illegal activities in the country.

3. Creation of Sound Investment Decisions: - forensic accounting helps in analyzing the financial standing and feebleness of a business, it provides a path for investors to make thoughtful investment decisions. A company dealing with fraud is definitely not a good option for investment. Therefore, the reports of forensic accountants act as a guide for potential investors of a company. Many organizations also apply for loans from various financial institutions. By performing an analysis, such institutions can take a decision on whether they would like to fund a company or not.

4. Gratifying Career Opportunity: - forensic accounting is extremely gratifying, as it not only embroils regular accounting activities, but also embroils identification, analysis, and reporting of the findings during an audit. The acceptance of reports generated by a forensic accountant by the court of law, gives them an upper hand as compared to other accountants

\section{DEMERITS OF FORENSIC ACCOUNTING}

1. Confidentiality issue: - since the scrutiny of a company's financial records is done by an external forensic accountant, the chances of seepage of confidential matter are always there. It is true that their code of ethics clearly mentions that forensic accountants and other members intricate in the scrutiny must not engage in disclosing confidential data to outsiders, but the possibility of disclosure cannot be nullified.

2. Increases chances of intimidations and negative publicity :- If the analysis of a company's financial statements points out the immersion of a particular person in fraudulent activities, there is a significant chance that the person will try to threaten the company to safeguard himself from the trial. Also, any trial 


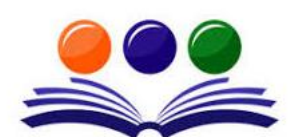

GRAND ACADEMIC PORTAL RESEARCH JOURNALS

\section{A GLOBAL JOURNAL OF SOCIAL SCIENCES}

( ISSN - 2581-5830 )

Impact Factor: SJIF - 4.998, IIFS - 4.375

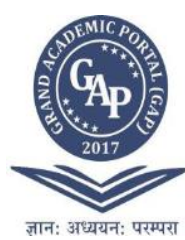

that confirms a fraud happening in the company comes under public eye and gains negative publicity, which directly affects the reputation and investor relations of the company.

3. Expensive Process: - Forensic accounting can be acostly affair because the procedures which accountants use embroil high-end accounting software. If study results have to be presented in a trial, the overall expenditure goes up even further. This can be a matter of concern for the organization.

4. Partial Use of Services:-federal regulations frontier the use of services from a single accounting firm. Suppose a company has tied up with one firm for auditing, it cannot ask the firm to provide other services. Therefore, a company has to reach out to numerous firms for carrying out its accounting tasks. Despite the drawbacks associated with forensic accounting, it is, and will continue to be an important part in the world of business. This is because it helps organizations and individuals to figure out whether their financial accounts are accurate or fabricated to hide illegal activities going on within the organization.

\section{AWARENESS OF FORENSIC ACCOUNTING IN INDIA}

As compared to other foreign countries India is lacking behind in the area of forensic accounting. Due to rapid increase in scams and white-collar crimes in India, forensic accounting has come into the limelight and there is gigantic requirement for forensic accountants. These days various organizations like India forensic, Institute of Chartered Accountants of India (ICAI), and Association of Chartered Certified Accountants (ACCA) offer courses on forensic auditing in India.

Table 2: Framework of Forensic Accounting Forensic Accounting

(Integration of Accounting, Auditing and Investigation Science)

\begin{tabular}{|c|c|c|}
\hline Accounting & Auditing and Assurance & $\begin{array}{ll}\text { Auditing } & \text { and } \\
\text { Assurance } & \end{array}$ \\
\hline $\begin{array}{l}\text { Looking beyond numbers while } \\
\text { examining financial reporting and } \\
\text { business information systems. } \\
\text { Compliance of GAAPs and IFRS/ } \\
\text { Regional standards. Reframing of } \\
\text { accounts based } \\
\text { on legality and GAAPs. }\end{array}$ & $\begin{array}{l}\text { Risk assessment and analytical } \\
\text { procedures. } \\
\text { Designing and Performing } \\
\text { Extended audit procedures. } \\
\text { Compliance of standards of } \\
\text { auditing, where applicable. } \\
\text { Introspective and sceptical mind } \\
\text { set for reviewing transactions and } \\
\text { deals. }\end{array}$ & $\begin{array}{l}\text { Fixation of direction of } \\
\text { Investigation } \\
\text { realistic basis. } \\
\text { Gathering evidences } \\
\text { and clues } \\
\text { through scientific and } \\
\text { latest } \\
\text { investigation } \\
\text { techniques. } \\
\text { Analysis } \\
\text { psychological } \\
\text { behaviour of human. } \\
\text { Evidence } \\
\text { documentation for } \\
\text { legal proceedings. }\end{array}$ \\
\hline \multicolumn{3}{|c|}{$\begin{array}{l}\text { Litigation Consultancy- Jointly working with lawyers and clients engaged in litigation to provide expert } \\
\text { advice regarding evidence and strategic proceedings. } \\
\text { Computer Forensic - Providing assistance in Electronic data recovery and retrieval. } \\
\text { The Expert Witness- Providing evidence and preparation of formal reports for filing in the Court of Law. }\end{array}$} \\
\hline
\end{tabular}

\begin{tabular}{|l|l|l|l|}
\hline $\begin{array}{l}\text { Sr. } \\
\text { No. }\end{array}$ & Accounting & Auditing & $\begin{array}{l}\text { Forensic Accounting(FA)/ } \\
\text { Investigation Science }\end{array}$ \\
\hline $\mathbf{1}$ & $\begin{array}{l}\text { Financial Accounting is the } \\
\text { preparation of financial } \\
\text { statements based on } \\
\text { Generally Accepted } \\
\begin{array}{l}\text { Accounting } \\
\text { Principles(GAAP) }\end{array}\end{array}$ & $\begin{array}{l}\text { Auditing is specifically } \\
\text { checking to see if the } \\
\text { accounts and/or systems } \\
\text { conform to a pre-defined } \\
\text { set of specifications } \\
\text { (GAAP in this example, } \\
\text { preparation accounting is the } \\
\text { statements based on Generally } \\
\text { but there are all sorts of } \\
\text { audits) }\end{array}$ & $\begin{array}{l}\text { Forensic Accounting is investigative. } \\
\text { are } \\
\text { patterns. Generally I've seen this in } \\
\text { support of some sort of legal process. } \\
\text { The outcome is less general (an audit } \\
\text { report), and is generally useful as } \\
\text { evidence in court with regard to } \\
\text { certain occurrences (where did my } \\
\text { cash go; why did this customer get } \\
\text { Principles (GAAP). It follows a } \\
\text { set of rules and guidelines }\end{array}$ \\
\hline
\end{tabular}




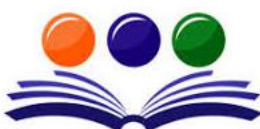

GRAND ACADEMIC PORTAL RESEARCH JOURNALS

( ISSN - 2581-5830 )

Impact Factor: SJIF - 4.998, IIFS - 4.375

\begin{tabular}{|c|c|c|c|}
\hline & $\begin{array}{l}\text { prescribed and regulated by } \\
\text { the Financial Accounting } \\
\text { Standard Board (FASB). }\end{array}$ & & $\begin{array}{l}\text { the going rate for sand; etc). Note it is } \\
\text { a done-thing to use FA outside of a } \\
\text { legal context, so it isn't just } \\
\text { constrained there. }\end{array}$ \\
\hline 2 & $\begin{array}{l}\text { Financial Accounting is } \\
\text { communicated to the internal } \\
\text { management without any } \\
\text { further interpretations }\end{array}$ & $\begin{array}{l}\text { Auditing is designed to } \\
\text { provide an overall } \\
\text { opinion on financial } \\
\text { reporting in some form, } \\
\text { but limited review for } \\
\text { particular issues, } \\
\text { particularly "negative" } \\
\text { issues, and do not } \\
\text { involve detailed specific } \\
\text { analyses. }\end{array}$ & $\begin{array}{l}\text { Forensic Accounting is much more } \\
\text { detailed and focused, particularly to } \\
\text { fully understand a specific issue or } \\
\text { family of issues, and often used in } \\
\text { resolving disputes, including } \\
\text { litigation support. }\end{array}$ \\
\hline
\end{tabular}

\begin{tabular}{|c|c|c|c|}
\hline 3. & $\begin{array}{l}\text { Financial Accounting } \\
\text { shows that the } \\
\text { Statements prepared are } \\
\text { as per the True \& Fair } \\
\text { View of the business. }\end{array}$ & $\begin{array}{l}\text { Auditing simply means the opinion } \\
\text { of Independent auditors on } \\
\text { preparation of financial statements } \\
\text { by the management of the company } \\
\text { in context of statutory audit and } \\
\text { mandatory for public and private } \\
\text { companies }\end{array}$ & $\begin{array}{l}\text { FA simply means effective } \\
\text { evidences congregated by auditors } \\
\text { which "appropriate for use in a } \\
\text { court of law" and mostly used by } \\
\text { government agencies. }\end{array}$ \\
\hline 4. & $\begin{array}{l}\text { It follows a set of rules \& } \\
\text { guidelines prescribed \& } \\
\text { regulated by Financial } \\
\text { Accounting } \\
\text { Board (FASB). } \\
\text { For publicly held } \\
\text { companies, financial } \\
\text { accounting also follows } \\
\text { standards set by the } \\
\text { Public } \\
\text { Accounting Oversight } \\
\text { Board (PCAOB). }\end{array}$ & $\begin{array}{l}\text { Auditing is simply examining } \\
\text { prepared financial statements as } \\
\text { per the need of the management. }\end{array}$ & $\begin{array}{l}\text { forensic accounting follows the } \\
\text { basic rules prescribed under } \\
\text { GAAP, it may depart from all or } \\
\text { parts of what is stated under } \\
\text { GAAP or FASB. In other words, } \\
\text { there are no set guidelines when it } \\
\text { comes to forensic accounting. }\end{array}$ \\
\hline 5. & $\begin{array}{l}\text { Each year Financial } \\
\text { Statements are prepared } \\
\text { in a same manner. } \\
\text { Financial accounting is } \\
\text { not performed on a } \\
\text { routine basis. }\end{array}$ & $\begin{array}{l}\text { Even in auditing of books of } \\
\text { accounts each case is handled } \\
\text { unanimously. }\end{array}$ & $\begin{array}{l}\text { Each case is handled differently, } \\
\text { using procedures that are } \\
\text { appropriate to fit the } \\
\text { requirements of the case. }\end{array}$ \\
\hline 6. & $\begin{array}{l}\text { It's Mandatory for all } \\
\text { public \& privet financial } \\
\text { institution. }\end{array}$ & $\begin{array}{l}\text { Mandatory \& optional as per the } \\
\text { nature \& type of audit }\end{array}$ & $\begin{array}{l}\text { Unlike financial accounting, } \\
\text { forensic accounting is not } \\
\text { performed on a routine basis, but } \\
\text { only when special circumstances } \\
\text { like those noted earlier warrant it }\end{array}$ \\
\hline
\end{tabular}

\section{ASPECTS FORENSIC ACCOUNTING}

The two major aspects within forensic accounting practices are:

1. Litigation support services. A forensic accounting expert measures the damages experienced by the parties implicated in legal disputes and can aid in settling conflicts, even before it reaches the courtroom. In the event that a conflict reaches the courtroom, the forensic accounting professional could give evidence as an expert witness.

2. Investigative/fact-finding services. A forensic accountant must determine whether illegal matters such as employee felony, securities embezzlement (including tampering and distortion of financial accounts), identity Techniques and tools of forensic auditing.

Conventional Techniques:

(Chakrabarti (2014), Moid (2016), Peshori (2015), and Shaheenet al. (2014) mentioned five techniques of forensic accounting for
Contemporary Techniques( The global professional services giant KPMG employed and suggested the use of following techniques of forensic accounting in the light of increasing sophistication and technology in the 


GAP GYAN
A GLOBAL JOURNAL OF SOCIAL SCIENCES
( ISSN - 2581-5830 )
\begin{tabular}{|l|l|}
$\begin{array}{l}\text { GRAND ACADEMIC PORTAL } \\
\text { RESEARCH JOURNALS }\end{array}$ \\
$\begin{array}{l}\text { detection and prevention of frauds. These } \\
\text { techniques canbe described as follows:) }\end{array}$ & commitment of corporate frauds and economic crimes:) \\
\hline Benford's Law & Spot the Unusual \\
\hline Theory of Relative Size Factor (RSF) & Fraud Risk Management \\
\hline Computer Assisted Auditing Tools (CAATs) & Forensic Technology Lab \\
\hline Data Mining Techniques & Corporate Intelligence \\
\hline Ratio Analysis & Verification (Know Your Employee) \\
\hline & Documentation Management \\
\hline
\end{tabular}

\section{FORENSIC ACCOUNTANT}

The faithfulness of the results found by Forensic Accountant depends on the knowledge, skills, and experience of the forensic accountant. A forensic accountant must be capable of incorporating knowledge and skills in the examination, analysis, interpretation, reporting, and testimonial support of evidence. In court, the forensic accountant can be an expert spectator, a consultant, or play other roles such as trier of fact, special master, court-appointed expert, referee, arbitrator, or mediator.

\section{MEANING OF FORENSIC AUDIT}

Investopedia defines - A forensic audit is an examination and evaluation of a firm's or individual's financial information for use as evidence in court. A forensic audit can be conducted in order to prosecute a party for fraud, embezzlement or other financial claims.

\section{OBJECTIVES OF FORENSIC AUDITING}

Following are objectives of Forensic Auditing

$>$ To use the forensic accountant's conclusions to enable a settlement, claim, or juries award by reducing the financial element as an area of ongoing deliberation

$>$ To elude fraud and mugging

$>$ To restore the demoted public confidence

$>$ To formulate and establish a wide-ranging corporate governance policy

$>$ To create a positive work environment

\section{PROBLEMS OF FORENSIC ACCOUNTING IN INDIA}

1. Forensic accounting is emerging field of financial fraud uncovering. There is acute scarcity of qualified accountants with adequate technical knowledge of forensic issues in India.

2. In India, politicians are involved in most of the financial fraud cases, so it is crucial to find evidences against them.

3. Indian judicial system still follows age old British judicial system. It is costly to bring the matter to court and hire expert advocates.

4. Due to liberalization and fast moving economy, more and more investors from foreign countries invest in India and so, it is difficult to litigate financial fraudster from other countries.

5. Because of continuous espousal of new techniques of Information and Technology by fraudster, it is difficult to Forensic Accountant to cope up with them.

6. Forensic accounting is a costly turf compared to other investigative turf.

7. It is voluntary for companies to appoint forensic accountant in companies.

8. There is no particular guideline or act on forensic accounting in India.

\section{LITERACY FOR FORENSIC ACCOUNTING IN INDIA}

Due to rapid increase in frauds and white-collar crimes, Forensic Accountants has come to the limelight recently. There is gigantic prerequisite for honesty, fairness and transparency in Indian Corporate reporting. The Institute of Chartered Accountants of India (ICAI) started a course on forensic accounting for only its members. It is "Certificate Course on Forensic accounting and Fraud Detection using IT and CAATs". At present, very few academic institutions are offering courses (full time or part time) on forensic accounting. Indian universities are lagging behind in this area as compared to other foreign universities. Some leading organization such as India-forensic (Pune, Maharashtra) started certificate Course in Bank Forensic Accounting 


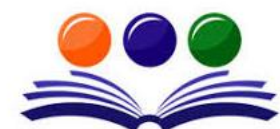 \\ A GLOBAL JOURNAL OF SOCIAL SCIENCES}

GRAND ACADEMIC PORTAL RESEARCH JOURNALS

( ISSN - 2581-5830 )

Impact Factor: SJIF - 4.998, IIFS - 4.375

$>$ Independence

$>$ Criminal Investigations

$>$ Shareholder's and Partnership Disputes

$>$ Giving initial advice as an personalize evaluation of the pleading and evidence available at the start of Proceedings.

$>$ Detecting the key documents which should be made available as evidence.

$>$ Preparing a detailed balanced report on quantum of evidence written in a simple language understood by a non-accountant.

$>$ Reviewing expert accounting reports submitted by the other party which may have impact on the quantum of evidence and advising lawyers on these reports.

$>$ Briefing legal counsels on the financial and accounting aspects of the case during pre-trial preparation.

$>$ The forensic accountant can initiate measures for introduction of environment accounting to highlight the damage done to the environment.

\section{SIGNIFICANCE OF FORENSIC ACCOUNTING AND SCAMS IN INDIA}

Forensic accounting in India has come to limelight only recently due to rapid increase in white-collar crimes and the belief that our law enforcement agencies do not have sufficient expertise or the time needed to uncover frauds. It is being used in banks, insurance companies and even police agencies (Preethi Singh, 2012). But India has witnessed hundreds of scams since independence. Some of the scams worth mentioning here are - Haridas Mundhra (1957), Nagarwala (1971), Antulay and cement (1982), Bofors (1989), the Fodder Scam (1990), The Hawala Scandal (1990-91), Harshad Mehta (1992), palmole in oil imports in Kerala (1992), Telgi (1995), SNC Lavalin in Kerala (1995), Sukhram and telecom (1996), fodder in Bihar (1996), Jain hawala (1997), Ketan Parekh (2001), the Barak missile (2001), Kargil coffins (2002), the Taj corridor (2003), the PDS scam in Arunachal (2004), oil for food (2005), Scorpene submarine deal (2006), 102 stamp papers (2005), cash for votes (2008), Satyam (2008), Madhu Koda and mining (2009), 2-G (2010), Commonwealth Games (2010), Adarsh Housing Society (2010), housing loans by banking and financial institutions (2010), Belekiri port in Karnataka (2010), food grains in Uttar Pradesh (2010) , Jayalalithaa assets case(1996-2014), and Bellary mines (2011) (Debroy \& Bhandary), Tatra truck Scam (2011),Indian Coal Allocation Scam(2012), Wakf Board Land Scam (2012), Chopper Scam (2013), Uttar Pradesh NRHM scam(2013),Vijay Mallya\& Kingfisher Airlines Scandal (2016), PNB Scam or Nirav Modi(2018), PMC Bank scam (2019), Laxmi Vilas Bank (2019), Roop Bhansali Scam, Subrata Roy, Saradha Scam NSEL Scam,

\section{FORENSIC ACCOUNTING IN INDIA}

$>$ Given the nature and types of fraud in India, the Reserve Bank of India (RBI) has compulsorily made forensic accounting audit mandatory for all banks within the country. The establishment of Serious Fraud Investigation Office (SFIO) in India has become the turning point for forensic accountants in the country. The indications of the growing demand for the field are:

$>$ The growing list of online criminal offences

$>$ Breakdown of regulators to trace and detect cyber-security frauds

$>$ The long chain of co-operative banks going bust

\section{FUTURE CHALLENGES OF FORENSIC ACCOUNTING IN INDIA}

$>$ As it is said that a forensic accountant is a bloodhound of accounting, not a watchdog. However in India, forensic investigators have to face various challenges while working which are discussed below:

$>$ Shortage of forensic investigators: In India, forensic accounting is yet a developing field in fraud detection. Therefore, there is an acute shortage of qualified accountants with adequate technical knowledge.

$>$ Political involvement: In India, most of the fraud cases involve politicians, so it is crucial to find evidences against them.

$>$ Judicial system: The Indian judicial system still follows the age-old British judicial system. Consequently, it is expensive to bring the matter to court and hire expert advocates.

$>$ Due to liberalization and a rapidly growing economy, more and more investors from foreign countries are investing in India, as a result it is difficult to sue financial fraudsters from other countries.

$>$ Technology: Because of continuous adoption of new techniques of Information and Technology by fraudster, it is difficult to Forensic Accountant to cope up with them. 


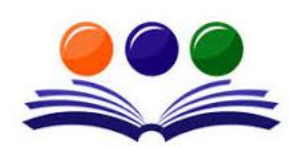

GRAND ACADEMIC PORTAL RESEARCH JOURNALS
A GLOBAL JOURNAL OF SOCIAL SCIENCES

( ISSN - 2581-5830 )

Impact Factor: SJIF - 4.998, IIFS - 4.375

\section{RELEVANCE OF FORENSIC ACCOUNTING IN AN ORGANIZATION}

> Assessing working transactions for compliance with basic operating processes and agreement.

$>$ Performing thorough scrutiny and examination of financial payment dealings in the accounting system to decide if they are standard or beyond company policy.

$>$ Assessing standard ledger and financial reporting system transactions for likely unlawful tampering or falsification of information or accounts and its consequences on the ensuing financial accounts.

$>$ Analysing warranty requests or returns for practices of fraudulence or misuse.

$>$ Assisting in estimating the economic damages and the ensuing insurance demands that arise from catastrophes such as fires or other natural setbacks.

$>$ Assessing or affirming business rating in consolidations and accomplishments.

\section{CONCLUSION}

Forensic accounting is the application of a specialized knowledge and specific skills. The major concern of the country is to prevent white collar crimes which affect the very fabric of the society. Forensic accounting has come up as an effective tool for preventing this menace. The practice and development of forensic accounting are relatively very much lower in developing countries like India than those in developed countries. As a matter of fact, there is no effective tool to measure, detect and prevent fraud and corruption in India; so, forensic accounting now appears as a one of the strategic and dynamic tool for the management of all types of corruption. It is still in a nascent stage and requires technological reinforcement on a continuous basis and global cooperation. It will develop as a specialized profession of accountancy and its importance to law enforcing agencies and also regulators will increase day by day forensic accounting engagement: how it is conducted since each and every fraud and financial irregularity is unique, accordingly the approaches to be adopted to unveil each of them will be specific to it. Association of chartered certified accountants (ACCA) has provided guidelines to perform such audit in general.

Forensic Accounting should not become a matter of specialization and expertise of a chosen few. It should be made a part of the curriculum at the undergraduate as well as the post-graduate level across the country. This will help the corporate and the government to keep a check on crime at the outset only. At the same time, requisite amendments in the law should be undertaken to establish the importance of forensic accounting in general and forensic accountants in specific.

\section{REFERENCES}

[1] Joshi, M. S. (2003), “Definition of Forensic Accounting” www.forensicaccounting.com.

[2] Poonam \&NeetuDhayal "Forensic Accounting: A Tool for Detecting and Preventing Frauds",International Journal of Multidisciplinary Approach and Studies ISSN NO:: 2348 - 537X.

[3] Prof. MeghaNaik, "Challenges and Scope of Forensic Accounting in India", International Journal for Research in Engineering Application \& Management (IJREAM) ISSN : 2454-9150 Special Issue NCCDCM21C - 2019

[4] Parul Shair, "PROSPECTS AND TECHNIQUES OF FORENSIC ACCOUNTING IN INDIA", International Journal of Research in Economics and Social Sciences (IJRESS),Vol. 7 Issue 8, August- 2017, pp. 604 614,ISSN(o): 2249-7382.

[5] Dr. Manas Chakrabarti, "Problems and Prospects of Forensic Accounting Profession in India", International Journal of Informative \& Futuristic Research, vol. 2, issue -1,September-2014, ISSN(0): 2347-1697.

[6] Mr. Pema Lama, Mr. Brahma Chaudhuri, "Forensic Accounting: A Study Of Its Role In Investigating Corporate Frauds And Scams In India”, 11th international conference on Science, Technology and Management (ICSTM-18) ISBN:970-93-86171-94-8

[7] Dr. Mahua Biswas, Kiran G Hiremath, Shalini R, "Forensic Accounting In Indian Perspective", The 5th International Conference on Financial Criminology (ICFC) 2013 "Global Trends in Financial Crimes in the New Economies".

[8] Ifath Shaheen, Pranathi, Asra Sultana, Amathun Noor, "Forensic Accounting and Fraud Examination in India", International Journal Of Innovative Research \& Development, November, 2014 (Special Issue) Vol 3, Issue 12,Issn 2278 - 0211 (Online) 
